\title{
Nad novelou zákona o vysokých školách
}

\section{Vážení čtenáři,}

po letech opakovaných pokusů změnit zákon o vysokých školách se nyní zdá, že toto úsilí nabývá jasnějších obrysů v podobě paragrafovaného znění rozsáhlé novely vysokoškolského zákona. Je pravdou, že do platnosti této novely je nutné, aby ještě úspěšně prošla úskalími legislativního procesu, ale bez ohledu na to je možně si položit otázkou, co mohou navrhované změny do vysokoškolského prostředí přinést.

Na počátku musím říci, že si nejsem zcela jist, zdali vůbec víme, v čem jsou slabá místa našich vysokých škol a hlavně, zdali víme, jak je lze řešit. Základní problém vidím v tom, že v poslední době sice často slýcháme o nezbytnosti zásadní reformy vysokého školství, ale o konkrétních důvodech se většinou již tolik nemluví. Zdá se mi totiž, že z viditelných problémů a nízké úrovně jedné školy se udělá závěr o stavu celého našeho vysokého školství, analýza úrovně škol se víceméně omezí na konstatování, že pokulhávají za prestižními světovými univerzitami a návod na řešení sklouzne do ,,je třeba zvýšit kvalitu“. Nejde o to, že by na těchto tezích nebylo něco pravdy, avšak pro hledání úspěšné budoucnosti našeho vysokého školství jsou př́iliš obecné.

Pokud chceme zvýšit úroveň našich vysokých škol, je třeba na jedné straně velmi konkrétně podle jednotlivých oborů a se znalostí podmínek našeho současného vysokého školství popsat, jaké jsou hlavní problémy, z čeho pramení, a na straně druhé definovat, $\mathrm{k}$ jakému cíli bychom měli směřovat. A z toho potom odvodit konkrétní kroky, které budou naše vysoké školy tímto žádoucím směrem posouvat.

Podíváme-li se na základní body novely zákona, mohlo by se zdát, že jde tímto směrem. Akcent na zvýšení kvality vysokých škol nelze změnám v zákoně upř́it, školy samy by měly zrrídit orgán pro vnitřní hodnocení kvality, který by měl vyhodnocovat kvalitu a přijímat opatření $\mathrm{k}$ jejímu zajišt’ování. Za významnou změnu možná bude považováno i posílení postavení národní akreditační agentury jako strážce úrovně a kvality celého našeho vysokého školství.

Zásadní otázkou však zůstává, zdali jsme skutečně schopni kvalitu spolehlivě a smysluplně měřit. Většinou se totiž sklouzne $\mathrm{k}$ nějakým kvantifikacím toho, co lze kvantifikovat (trochu stranou zůstává smysluplnost takové kvantifikace a dopady, jaké to přinese), či slovnímu hodnocení, které zase často vyústí do květnatých zpráv, jež jen obtížně hledají své pozorné čtenáře a hlavně neposkytují využitelnou informaci o současném stavu a možnostech jeho zlepšení.

Proto jsem poměrně skeptický $\mathrm{k}$ tomu, zdali za této situace vytvoření orgánu pro vnitřní hodnocení kvality přinese něco nového. Ani změna v postavení akreditační agentury sama o sobě nepřinese zněnu v její činnosti. Otázkou podle mého názoru stále zůstává, zdali takto koncipovaný orgán, jehož členové pocházejí z institucí, které samy jsou předmětem akreditací, je objektivně schopen posuzovat kvalitu jednotlivých škol a oborů. Zaváděné institucionální akreditace by jí mohly uvolnit kapacity pro posuzování žádostí o akreditace ze škol, které vyžadují "více pozornosti", ale výše zmíněné problémy to př́iliš neřeší. 
A tak zůstává otázkou, zdali novela zákona bude mít skutečný reálný dopad na úroveň našich vysokých škol. Co je však nesporné, je poměrně velké administrativní zatížení, které bude spojeno s ,přeakreditací“ programů, zrrízením orgánu pro vnitřní hodnocení kvality či změnou řady vnitřních předpisů vysokých škol.

Nejde o to, že by záměry vtělené do novely zákona byly chybné. Obávám se však, že se změny budou odehrávat spíše $v$ administrativní rovině. Úroveň škol se v realitě odvíjí od něčeho jiného. Je primárně dána př́istupem a odpovědností studentů a učitelů, jejich zájmem a motivací co nejvíce se naučit, objevit něco nového a starat se dobré jméno své školy. A to vše se zákonem př́liš změnit nedá, $\mathrm{k}$ tomu povede pouze konkurence mezi školami, tlak ze strany zaměstnavatelů na úroveň absolventů. Neupínejme tedy ke změně zákona př́liš velká očekávání. Nevěřme příliš na to, že kvalitu škol je schopen nějaký orgán objektivně posuzovat a kontrolovat. Učme se spíše všichni, že tak jako vybíráme např. auto podle kvality značky, musíme vybírat vysokou školu podle jejího jména - a to at' již budeme vybírat školu, kde budeme chtít studovat či odkud zaměstnáme absolventy. Nesmíme zapomínat na to, že dokud bude existovat poptávka po titulech bez adekvátních znalostí, budou existovat i vysoké školy bez potřebné kvality. Tyto školy ale naštěstí úroveň našeho vysokého školství neurčují!

doc. Ing. Petr Dvořák, Ph.D.

děkan

Fakulta financí a účetnictví

Vysoká škola ekonomická v Praze 